This item was submitted to Loughborough's Institutional Repository (https://dspace.lboro.ac.uk/) by the author and is made available under the following Creative Commons Licence conditions.

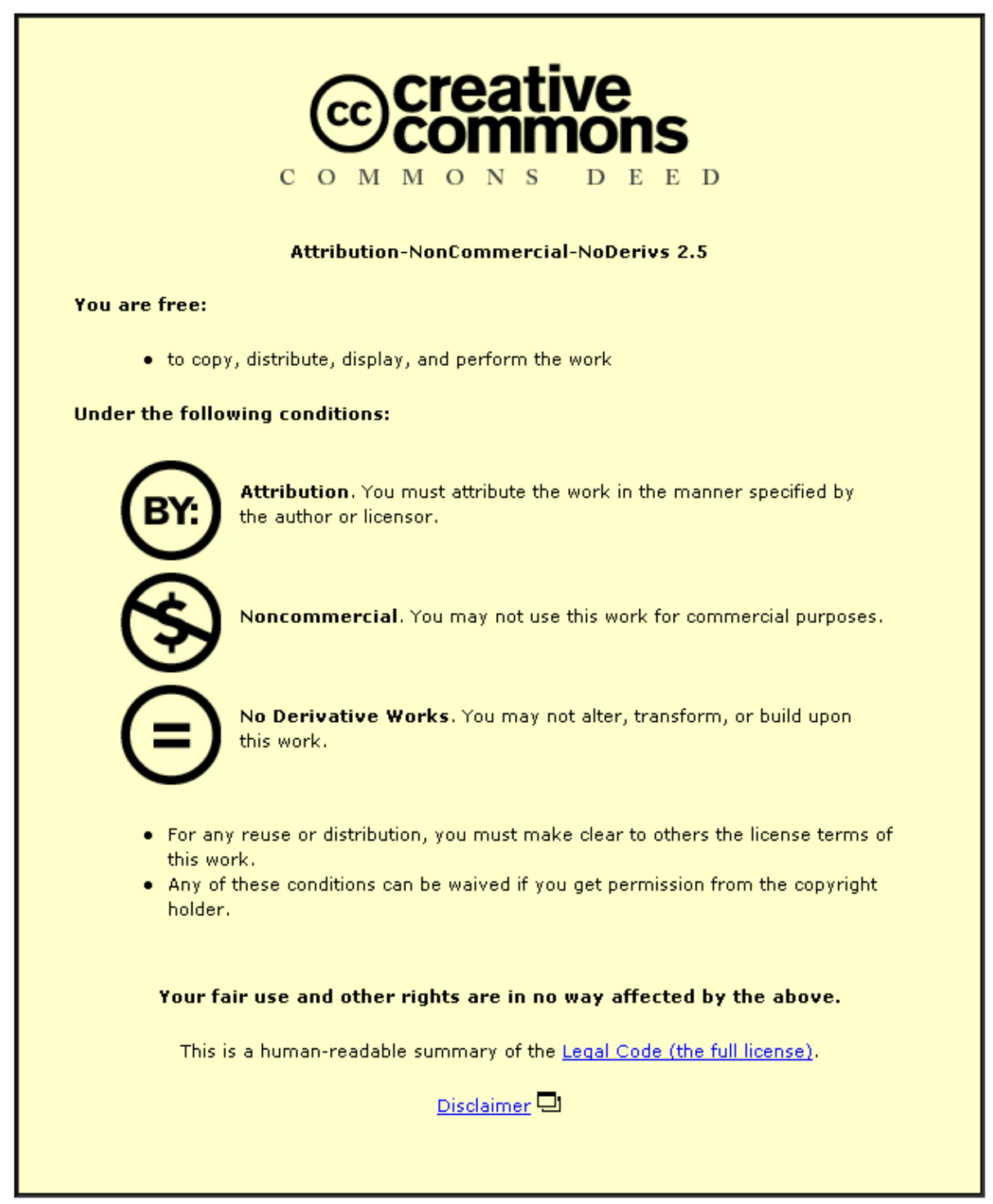

For the full text of this licence, please go to: http://creativecommons.org/licenses/by-nc-nd/2.5/ 


\title{
Duty to God/my Dharma/Allah/Waheguru: Diverse youthful religiosities and the politics and performance of informal worship
}

\author{
Sarah Mills \\ Department of Geography, Loughborough University
}

To cite this paper:

Mills, S. (2012) Duty to God/Dharma/Allah/Waheguru: Diverse youthful religiosities and the politics and performance of informal worship, Social \& Cultural Geography 13 (5): 481-499

\begin{abstract}
This paper draws on a case study of the Scout Movement in the UK to explore the everyday, informal expressions of 'worship' by young people that occur outside of 'designated' religious spaces and the politics of these performances over time. In analysing the explicit geographies of how young people in UK scouting perform their 'duty to God' (or Dharma and so forth), it is argued that a more expanded concept of everyday and embodied worship is needed. This paper also attends to recent calls for more critical historical geographies of religion, drawing on archival data to examine the organisation's relationship with religion over time and in doing so contributes new insights into the production of youthful religiosities and re-thinking their designated domains.
\end{abstract}

Keywords: religion; youth; Britain; Scout Movement; worship; archival research

\section{Introduction}

Recent work on the geographies of religion has started to move 'beyond the officially sacred' (Kong 2005: 615) with a range of studies on the everyday geographies of religion 'that lie beyond the church and chapel' (Brace, Bailey and Harvey 2006: 38). There has also been an important focus in social and cultural geography on the intersection between the religious and the secular; for example, through research on sartorial politics (Gökariksel 2009), grief and bereavement (Maddrell 2009), statesponsored religious speech (Howe 2009) and transnationalism (Sheringham 2010). In both cases, geographers have contributed to wider academic debates spearheaded by the 
sociology of religion on secularisation and various forms of belief and institutions (Vasquez and Marquardt 2003; Gorski and Altinordu 2008; Rosati 2010). This paper attempts to bring young people firmly into the spotlight when going 'beyond the officially sacred' (see also Brace, Bailey and Harvey 2006), drawing on recent work on ‘youthful religiosities' (Hopkins, Olson, Pain and Vincett 2011) to interrogate the complex and messy 'in-betweenness' of religion, spirituality, faith, belief, and secularism in the context of young people and youth spaces that have been somewhat neglected (on definitions of religion and spirituality and theorising these concepts, see Johnstone 2006; Proctor 2006). In doing so, this paper calls for an exploration of different conceptions and spatialities of ‘worship’ across a wide-ranging spectrum of religious and non-religious youth. Here, I draw on the case study of the Scout Movement in the UK and its diverse geographies of religion to explore the politics and performance of informal worship by young people outside of formal religious spaces and school. Indeed, when there has been work on young people and religious spaces, the focus has mainly been on state-level educational structures or spaces within religious communities (Dwyer 1993; Valins 2003; Kong 2005; Harvey, Brace and Bailey 2007; Hemming 2011a) as part of an increasing interest in education spaces more broadly (Cook and Hemming 2011).

These discussions have a wider social importance as well as academic value. Contemporary debates on school prayer in the US (Delfatorre 2004) and the place of religion in the English education system, for example in school 'ethos' (Hemming 2011b) demonstrate the often polemic opinions on the role and 'place' of religion in spaces for children and young people. This paper's central contribution is therefore to highlight the importance of other arenas of youth work in understanding the politics of 
informal worship and the 'complex realities and difficulties of multi-ethnic and multireligious life in a (post)modern world' (Valins 2000: 584).

Scouting is an informal volunteer youth organisation with a worldwide membership of around 30 million young people. The politics of scouting and its religious policies varies by national association. However, there is a historic global structure to scouting with the administrative centre of the World Organisation of the Scout Movement (WOSM) based in Geneva (Vallory 2012) whose policies and practices on religion refract debates in domestic scouting nations, none more so than the 'spiritual' home of scouting in the UK. Focusing on the Scout Association in the UK, this article aims to expand concepts of everyday and embodied worship by analysing its geographical diversity and complex relationship with religion. I contend that scouting in the UK can act as a 'lens' through which to view wider societal changes and shifts in attitudes towards religion and tensions therein.

The Scout Association encourages individual spiritual development and interprets its religious philosophy as open and inclusive, yet it is often sidelined locally by adult volunteers in favour of more adventurous and less controversial activities. Furthermore, the organisation is stereotyped as Christian, yet has always had (sometimes hidden) multi-faith expressions and articulations. Indeed, the organisation requires its members to promise to do their 'duty to' either 'God' (Christianity, Judaism), ‘my Dharma’ (Hinduism), ‘Waheguru’ (Sikhism), ‘Allah’ (Islam) or 'my religion' (Buddhism, Taoist, Confucians). The example of scouting is therefore unique as a multi-faith site of informal youth work in civil society, one whose main aim is not religious education and yet has religious characteristics embedded in its policies and practices. My focus in this paper is not on one particular religious community in scouting, but rather I examine the negotiations and re-articulations of religion in 
scouting that have emerged in different times and contexts in order to theorise the politics and performance of informal worship in young people's spaces. To do so, this paper specifically analyses two examples where religion 'appears' in scouting - prayers and the Scout Promise.

These examples shift attention within geographical literature on the relationship between the religious and the secular towards a more explicit consideration of young people and their informal, mundane and perhaps even banal religious encounters embedded in their everyday lives. In analysing how a number of different quasireligious multi-faith practices are performed by Scouts, and in some cases transformed over space and time, I also build on Fraser MacDonald's (2002) call for geographers to pay closer attention to the concept of 'worship'. I emphasise the role of the everyday in spiritual (scouting) practice (Holloway 2003) and the embodied and sonic geographies of worship performed by Scouts. One can therefore see the Scout Association as an alternative or hybrid space that is infused with formal and informal religious and spiritual practices. In exploring these ideas, this paper echoes Maddrell's argument in her paper on the practices of death rituals and bereavement that "there needs to be a more nuanced understanding of the widening spectrum of beliefs and related practices in societies such as the UK, which are simultaneously exhibiting high levels of at least nominal religious identity, increasing varieties of faith, and secularisation, as well as how both of these trends intersect with increasingly individualised practices.” (2009: 677)

Furthermore, through drawing upon archival material over the course of the organisation's centennial history, this paper uniquely shows how (adult) ideas about young people's beliefs and religious identity have emerged and been spatialised over time. This study therefore offers one way to contextualise recent debates on 
multiculturalism, secularism and youthful religiosities. Indeed, historical geographies of religious performances remain surprisingly under-developed in the geographic literature (Brace, Bailey and Harvey 2006; for studies in history on religious diversity in Britain since 1945 see Wollfe 1993). In exploring the emergence and development of everyday sites of multi-faith religious practice and spirituality in scouting, I argue that studies into the ways in which religion shapes people's experiences over space need to be complemented by interrogating the temporalities of religious diversity.

This paper is structured in a number of sections. First, I introduce the study-area and expand on the literatures surrounding geographies of religion and youth. Second, I explore the religious philosophy and pedagogy of 'Duty to God' embedded in the Scout Movement. I then draw upon two examples of 'worship', a concept differentially understood in scouting; through illustrations of prayer and the Scout Promise, I highlight not only the diversity of religious performances in scouting but the varied responses to these alternative performances of 'Duty to' other deities. Overall, in using a geographical approach to explore the spaces, practices, politics and performance of informal worship in scouting, this paper uses these empirical examples in order to suggest a more nuanced understanding of the politics and performance of alternative and informal types of 'worship' and the everyday, mundane and banal instances where these 'appear' in young people’s spaces.

\section{Geographies of Religion and Youth: Informal, Institutional and Historical}

\section{Interventions}

Geographical research on youth and religion has primarily been concerned with contemporary explorations of young people's identities and beliefs, tied up with broader ideas on citizenship and belonging (for comprehensive reviews on the geographies of 
religion more broadly, see Holloway and Valins 2002; Yorgason and della Dora 2009 both in this journal; Kong 1990, 2001, 2010). These studies have mainly examined Muslim youth (Dwyer 1998, 1999; Hopkins 2006, 2007a, 2007b), though other work on religious youth is emerging, for example on young Christians in Scotland. Hopkins, Olson, Pain and Vincett (2011) argue that there are 'diverse influences on the religiosity of young people - from institutions, religious leaders, culture, peers, as well as the family' (2011: 316). Indeed, much work in sociology has explored religious change in Britain in relation to age, parental transmission and the lifecourse (Voas and Crockett 2005). I would add to these influences the role of informal youth work, indeed Hopkins, Olson, Pain and Vincett do briefly note the role of Boys’ Brigade officers in some of the participant's responses (2011: 320-321). Here, I want to specifically focus on one such youth scheme - Scouting in the UK - in order to map out future conceptual directions for understanding the "intersections of sacred and secular" (Kong 2005: 615).

In terms of more formal environments for young people, geographers have examined the relationship between religion and educational spaces. This includes research on Muslim schools in the UK (Dwyer 1993) and Singapore (Kong 2005), Jewish Day Schools in Britain (Valins 2003) and a multi-faith primary school in the north of England (Hemming 2011a). These studies have importantly examined the complex relationship between state-level visions of 'education', multiculturalism and modernity, as well as parental opinions on their children's academic and religious development. There are, however, a number of other diverse spaces that are not part of compulsory education, or run by organised institutional religious groups, through which young people are introduced to, negotiate, and contest ideas about both their own and others religious beliefs, such as religious volunteering schemes (Hopkins, Baillie-Smith, Laurie and Olson 2010) or fieldwork at university (della Dora 2011). There remains 
great scope, therefore, to interrogate the varied, informal and banal encounters of young people with religious sites and settings, particularly in the context of religious change in twentieth century Britain (Crockett and Vaos 2006). In this paper, I suggest one way in which work on the geographies of youth and religion could usefully expand through examining a site where different religious youth (and indeed non-religious youth) meet and engage with an informal organisation that has a complicated yet explicit relationship with religion. Geographic analyses of adult attempts to (religiously) educate young citizen-subjects have the potential for wider theoretical contributions. For example, Adrian Bailey, David Harvey and Catherine Brace’s work on Methodist Sunday schools in nineteenth century Cornwall (Harvey, Brace and Bailey 2007) and its religious-moral geographies of temperance (Bailey, Harvey and Brace 2007) considers not only the symbolic and spiritual role of young people in the life of religious communities, but contributes to understandings of subjectivity and youth citizenship.

Thus far, when there have been geographical studies on religion that have utilised historical data, the spotlight has largely been on medieval, Christian or Abrahamic based religious communities (see Valins 2000; Harvey 2002; Brace, Bailey and Harvey 2006; Harvey, Brace and Bailey 2007, although for an exception see Naylor and Ryan 2003). I seek to move this literature on by focusing on non-Christian - and indeed multi-faith - historical geographies of religion and youth, in this case, through youth movements. Uniformed youth movements emerged at the end of the nineteenth and beginning of the twentieth century (Springhall 1977) and were framed explicitly along religious lines, for example the Christian based Boys’ Brigade (Springhall, Fraser and Hoare 1983; Kyle 2007) and Jewish Lads and Girls’ Brigade (Kadish 1995). These schemes framed their rationale and purpose in terms of staunch direct religious instruction for youth. While later youth movements such as the Woodcraft Folk 
founded in 1925 were secular (Davis 2000), the most popular British youth movement the Boy Scout Association - founded in 1908, had a flexible yet still committed religious element.

\section{Spatialities of Scouting and Methodology}

The emergence of scouting, the publication of Scouting for Boys and the life of founder Robert Baden-Powell have been well studied by historians (Warren 1986; Jeal 1991; Boehmer 2004). An informal youth citizenship training scheme inspired by imperial anxieties surrounding the morality and manly character of Britain’s youth, 'scouting' was trialled at a camp in 1907 and quickly developed as a youth organisation in Britain and abroad. Baden-Powell's ideas were mobilised through a series of moral geographies about behaviour and fitness, practised through methods of adventurous woodcraft and outdoor learning, and based on ideals of patriotism and chivalry (Mills, in press). It was a specifically male vision of an 'ideal' Scout and there was a particular set of ideas about appropriate masculinities, strongly connected to ideas of (religious) moral behaviour. These messages were communicated and translated to Scouts through three levels of duty to which they should aspire: duty to self, to others, and to God. This final element of a Scout's commitment has proved to be the most contentious, and yet it remains a neglected empirical example in historical studies of scouting that have centred on its early development and international growth (Proctor 2002; Block and Proctor 2009). As well as being a useful empirical contribution to this scholarship, this paper draws upon this example in order to make a broader argument about understanding young people’s everyday spaces which utilise aspects of religious worship in the formulation of particular types of citizen-subject. The following sections interrogate scouting's complicated, subtle and yet increasingly problematic relationship with 
religion through examining the particular geographies of scouting spiritual practice over time.

I draw upon a variety of sources that were part of a larger research project on the cultural-historical geographies of scouting. I collected a range of written, oral, fictional and image-based material from the archive at the Scout Association Headquarters at Gilwell Park in Essex, UK. In terms of specifically analysing the organisation’s relationship with religion, I have consulted correspondence, minutes of religious panels and advisory groups meetings, publicity leaflets, magazines, photographs and artwork. These were coded thematically and analysed through visual and textual analysis. I also collected and analysed data from websites, online discussion boards, magazines and semi-structured interviews with members of staff and volunteers. These interviews (six in total lasting approximately one hour each) were largely conducted as part of a much smaller research project on Muslim Scouting in Wales. Finally, I have drawn on my own personal experience as a volunteer Scout Leader at various meetings, events and camps. This role enhanced the research process through long-term critical reflections and direct encounters with the 'place' of religion in scouting across a range of contexts.

\section{Happy, Healthy, Helpful...Religious?: Spirituality and Scouting}

Robert Baden-Powell, son of a Church of England Priest, viewed the spiritual development of Boy Scouts as integral to the very attainment of good citizenship:

The aim of the Boy Scout Movement is now generally understood to be that of making Happy, Healthy, Helpful citizens i.e. good citizens. This implies...that they are possessed of, and practice religion (Baden-Powell 1931). 
The early philosophies and activities of scouting therefore involved a religious element, with Boy Scouts encouraged to become 'player[s] in God's team' (Baden-Powell 1922: 199). The promise members made to do one's 'Duty to God' was realised through specific performances and practical articulations constantly rehearsed by Boy Scouts. These varied locally, but mostly included attending religious services, prayers, singing, parading, storytelling and demonstrating environmental stewardship. Badge work and nature-study were used didactically to create educated and disciplined young (male) bodies 'ready to receive' religion:

Religion can and ought to be taught to the boy, but not in a milk and watery way, or in a mysterious and lugubrious manner; he is very ready to receive it if it is shown in its heroic side and as a natural everyday quality in every proper man, and it can be well introduced to boys through the study of nature (Baden-Powell 2004 [1908]: 314).

Some Church officials voiced concerns over 'nature worship...being considered a sufficient substitute for the worship of $\mathrm{God}^{1}$ and professed that camping must be 'supplementary to and not the sole quasi-religious exercise of the Sunday'. ${ }^{2}$ Whilst the philosophy of scouting presented religion as a process of self-discovery outdoors, assisted by adult volunteers, when it came to practising religion the organisation had a firm conviction that the requirements and wishes of parents - over attendance at religious services for example - were central, despite these interjections from Church leaders in the formative decades.

The organisation was independent of any singular religious body or Christian denomination and Baden-Powell was resolute that his pedagogy of religious development united Scouts through a 'required un-denominational and understandable 
religious basis' ${ }^{3}$ This point is crucial. It is not that the ideal scouting citizen envisioned by the Chief Scout was Christian, but that they would be open to spiritual development and be faithful to their parents' and own chosen belief. Despite this original flexibility, the movement became synonymous with a 'muscular Christianity' (Hall 2006) along with other schemes such as the Boys’ Brigade and Young Men’s Christian Association (YMCA). This Christian imaginary was perpetuated with popular representations of the organisation. For example, Scouter Ernest Stafford Carlos' The Pathfinder, one of a series of paintings on the fundamentals of scouting seen in Figure 1, became emblematic of the Movement and widely reproduced:

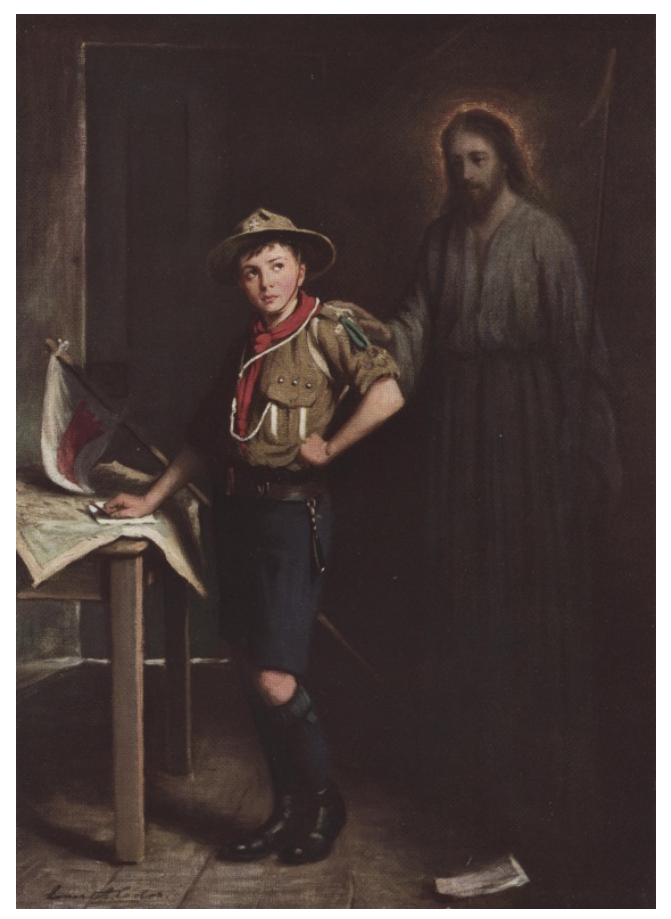

Figure 1: ‘The Pathfinder’, Ernest Stafford Carlos (1913), oil on canvas Source: With kind permission of the trustees of the Scout Association

Here, a 'model' Boy Scout, uniformed and planning an expedition, is overseen by the figure of Jesus Christ, an absent present, who, it is suggested, will guide this young citizen in the expedition of life. Despite these images, Baden-Powell described religion as an army who 'serves one king, though it is divided into different branches' (Baden- 
Powell 2004 [1908]: 230). An article on scouting in the Christian publication The Life of Faith in 1923 described this view as 'theistic, but absolutely non-Christian' (Kerr 1923) and warned religious leaders about aligning too closely with scouting:

What if we should one day wake up to the fact that the heart of our young life has been captured by a movement that officially has been inculcating the belief that Mohammed was as good as Jesus Christ, and, so far from it being necessary for a man to be converted, so long as he is religious, it does not matter? (Kerr 1923)

The Chief Scout was continually questioned about the religious openness of scouting during the 1920s, and often drew on his personal experience, encounters and travels to defend his viewpoint, replying to a letter of complaint in 1929 by stating:

I have been always friendly to all e.g. I have, though C.E. [Church of England] myself, attended any number of R.C [Roman Catholic] services, as well as those of non-conformists, etc. have called for greater deference to Jewish susceptibilities, and - breathe it not in Gath - have worshipped in the San Sofia mosque in Constantinople! ${ }^{4}$

The Chief Scout's wry comments defending what he saw as a genuine (inter-faith) brotherhood of scouting infuriated some clergymen and set the tone for a century of complex debate about the 'place' of religion in scouting.

The more flexible and inclusive wording of 'Duty to God' rather than 'Christ' has facilitated two trends over the last century. On the one hand, it has contributed to 
the increased internationalism of scouting, reflected in the development of scouting in countries such as India, Pakistan, the Middle-East and Thailand. On the other hand, there has been an increase in the numbers of non-Christian volunteers and youth in UK scouting, many of whom are from second-generation ethnic communities. These relationships between the Scout Association and these various faith-based communities have been formalised through a number of mechanisms. Scout Fellowships were established to support faith-based scouting, as well as a national Religious Advisory Panel with representatives from all religious bodies. ${ }^{5}$ Sponsorship agreements were also introduced for local places of worship to establish their own Groups, often meeting in ancillary buildings. These have usually been seen as the most 'appropriate' space for the religious development of Scouts, but the religious aspect of the organisation's programme remains a continued responsibility for all Scout Leaders. For example, in 1951, a Scout Association pamphlet entitled The Religious Obligations of Scouts stated:

It is clear that the Jewish Scout is best able to do his 'duty to God', whether in camp or elsewhere, in a Sponsored Group; but one of the most gratifying features of the Movement is the readiness of Scoutmasters of Open Groups to encourage the Jewish Scouts who come under their care to uphold the requirements of their faith. ${ }^{6}$

More recently, these sponsorship structures have been embraced by a number of religious communities and I have specifically explored the Muslim Scout Fellowship and contemporary Muslim Scout Groups elsewhere (Mills 2009). In this paper, I look at two specific examples that illustrate how everyday performances of 'worship' in scouting have been negotiated through diverse youthful religiosities: prayers and the 
Scout Promise. I do not focus on one specific religious community, but rather on these two features and soundscapes of scouting - echoing in unison between groups of young people - that have been negotiated over space and time. This thematic perspective also de-centres ideas about Christianity as an assumed default entry-point. It is also worth highlighting that whilst operating at the scale of the body as embodied 'spiritual' performances, these complex practices of scouting are also influenced and negotiated by local Scout Groups, the national organisation and the worldwide movement.

\section{Prayer, services and embodied 'worship'}

In defining its current principles of spiritual development, the organisation states that 'leaders and members should be encouraged to discover the need for prayer and worship, both personal and shared' (Scout Association 2010: 2). This individual and collective practice of prayer can take a number of forms, and alongside the Scout Promise (discussed later), illustrating the need for expanded concepts of 'worship' that include elements of religious performance or commitments to spiritual development. Whilst using the term 'worship' in this section, I wish to note, as MacDonald does, how worship as a term 'cannot as easily be used to describe the actions of devotees of Hinduism, Buddhism and Sikhism' (2002: 68). Examples of prayers in scouting include their use at national and international camps, regional services inside religious buildings such as Carol Services and Remembrance Day Parades, as well as more informal short prayers at the end of local Scout Group meetings.

There has always been provision in the organisation's religious policy that states 'where a Group consists of Scouts of various religions, they should be encouraged to attend the services of their own denominations, and Group church parades should not be held’ (Leonard (1948) [1933]: 14). However, joint events or mixed gatherings, in 
particular camps, have historically been a site of tension regarding mixed worship for their 'default' Christian hymns and prayers (on Christianity as a 'default' religion, see Hemming 2011a: 447). Reflecting on the 1929 World Scout Jamboree held in England, the Chief Rabbi stated that these acts of (Christian) worship 'naturally create a certain amount of difficulty' ${ }^{7}$ Over time, however, various parallel streams, options for withdrawal or alternative services have been developed. The most recognised alternative format is a 'Scout's Own', an inter-denominational Christian worship service originally devised by Scouter H. G. Elwes that is based on a thematic address to give a 'common base' to all religions. Instructions to Scout Leaders in 1933 stated that 'a Scouts' Own is not an opportunity for giving a lecture on woodcraft or on politics. It is a God's Own, every bit as much as it is a Scout's Own’ (Leonard (1948) [1933]: 26). These services have also been complemented with other readings, meditations and nonChristian acts of worship. For example, Baden-Powell included a reading from the Quran at a Scout's Own at Gilwell Park in 1923. After receiving an enquiry from Rev. Harvey, a prominent Scouter and Clergyman, about Baden-Powell's reasons for including this reading, the Chief Scout responded with a message of tolerance that:

They [Muslim Scouts] were broad minded enough to listen to our scriptures; it was not very much for us in return to listen to a chapter from the Koran...I am positive we did ourselves no spiritual harm but good from what we did that day. ${ }^{8}$

As well as different wordings or services, different spaces have been used, appropriated and transformed for the religious needs of some Scouts whilst on camp. I would argue that various sites and settings on camp become spiritual and sacred for a few minutes through the corporeal reconfigurations and rituals of prayer, whether standing on muddy 
fields outdoors, closing eyes inside of tents, sitting around the campfire, or kneeling on a sports hall floor:

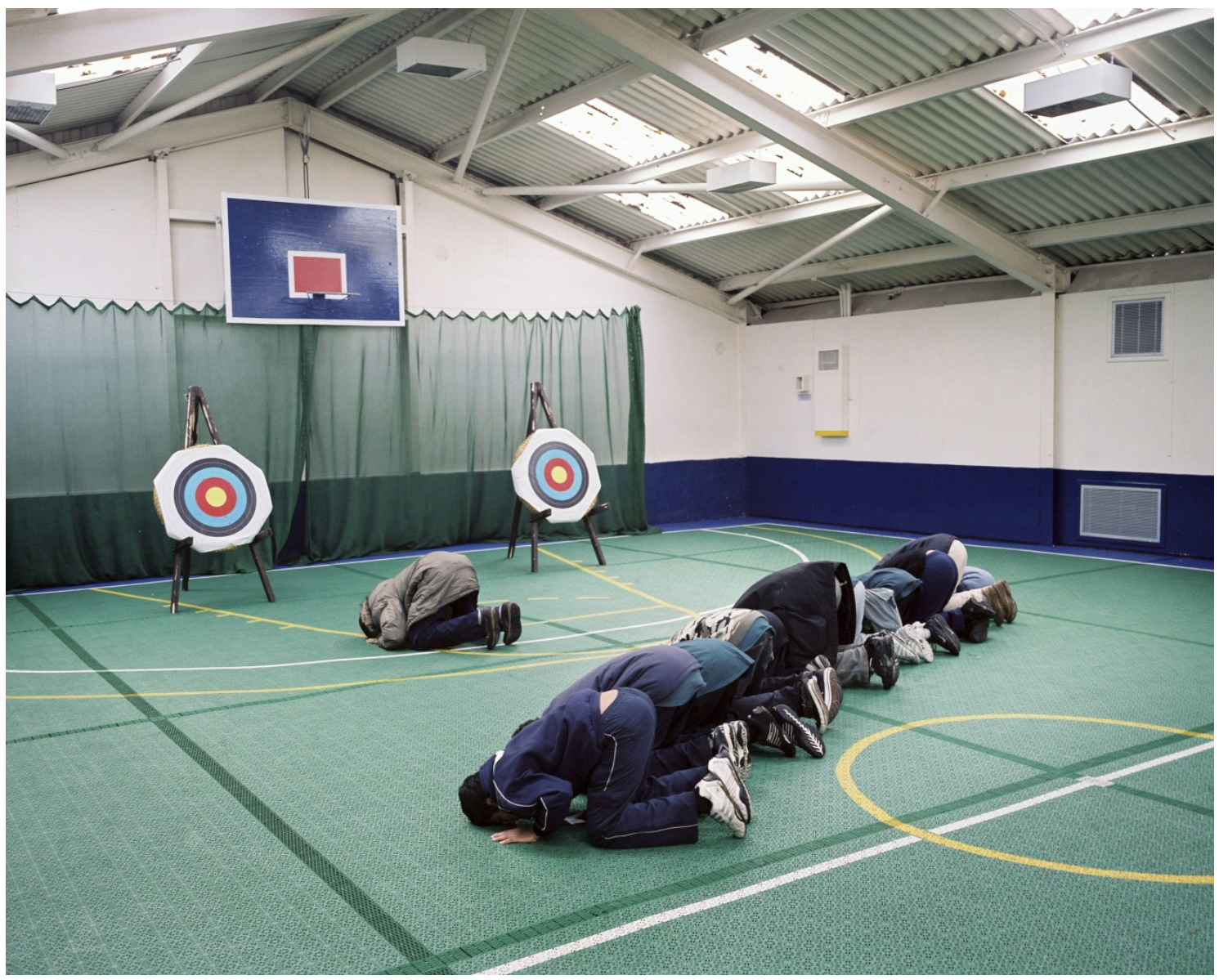

Figure 2: 'Breaking for midday prayers'

Source: With permission from Martin Kollar/Agence VU, Camera Press London.

Figure 2 shows Muslim Scouts from $304^{\text {th }}$ Birmingham Scout Group using a temporary space for prayer at Blackwell Court, an activity centre in Bromsgrove, West Midlands. This is one example of a different, profane and everyday environment 'beyond the officially sacred' where young people in scouting perform their religious identity and obligations away from home or a 'formal' religious building. In performing salat in an indoor hall set-up for archery, these Muslim Scouts are in some ways negotiating secular space (Gale 2007), as well as creating a new temporary space of spiritualness; a 
makeshift sacred space that, it could be argued, characterises much contemporary religious practice and worship (Dafydd Jones 2010).

This illustration contrasts examples given by Peter Hemming (2011a) where young people have had to negotiate situations where their religious needs were not ‘officially’ or institutionally catered for, for instance children praying in primary school toilets without adult knowledge (2011: 450). In comparison, scouting views spiritual development as an integral part of its aims and method, interweaving the performance of 'duty to God' (in this case, Allah) into the rhythms of scouting practice. This complicates understandings of how religious needs are 'met' by organisations, and academic approaches to multiculturalism, which often assumes a default position of struggle and hiddenness. Indeed, young people in scouting are actively encouraged to perform their religious duties rather than struggling to seek out space themselves. However, one could consequently argue that non-religious, atheist or agnostic youth are, by extension, marginalised and 'othered' in a youth organisation that dedicates time and space for religious expressions (on secularism and atheism see Davie 2000; Berger 2001; Connolly 2008; Yorgason and della Dora 2009). This creates a series of difficulties and is why many adult leaders choose to by-pass the religious programme of scouting or emphasise duty to 'self' and 'others' more than 'God'.

Local weekly meetings for age-based sections of scouting, lasting anywhere between 1 and 2 hours, often close with a prayer. In many ways, this is ritualistic and repetitive and the wording and style is often unique to that local Group (see MacDonald 2002). Formats include prayers spoken in unison by young people from memory, read out-loud by an individual Scout from a written sheet, or composed ad-hoc by an adult leader. These examples show the role adult volunteers as pedagogues have at a local level, determining the extent to which young people 'receive' or are exposed to, religion 
in scouting. It is also worth highlighting, from my own experiences in scouting and observations at other Scout Group meetings, how whilst these activities are going on, young people vary in their emotional responses: laughter, boredom, enthusiasm, ambivalence, and can be distracted by various other interests, friendships and objects.

These more regular instances of prayer in mixed local Groups can also be a site of tension and demonstrate the need for a flexible approach. For example, a development advisor for Black Minority Ethnic Communities at the Scout Association recalled a scenario at a Scout Group in Scotland that encountered the following request from the parent of a Beaver Scout (aged 6-8 years old):

The parent said I don't want my son to take part in that [prayer at end of meeting], because that's not the way, as a Muslim, that we pray and that's not how I want him to do it. So what happens then? Now, what they were saying in the prayer wasn’t the issue, what they were saying wasn’t denominational - it was something like 'Thank you for Beavers'. Well no-one has a problem with that; it's that action [places palms of hands together] which is perceived as being very Christian. The Beaver Scout Leader was like, what do I do? Well in this case, you need to come up with another thing to do because that's not appropriate. That might be that they just all stand there and close their eyes, or that might be that they all sit on the floor cross-legged (Development Advisor: Black Minority Ethnic Communities, Interview with Author).

Here, the movement of drawing two palms together (and the implication of bowing of heads and closing of eyes) is associated with a Christian expression of faith. By removing this element and replacing it with other corporeal configurations - such as 
sitting cross-legged - the prayer is seen as being altered into a different type of performance (Holloway 2003).

Adult volunteers are also encouraged to include a range of faith-based prayers into scout meetings, regardless of the religious demographic. As this factsheet states:

If appropriate, some aspects of Hinduism could be included in Scout meetings, e.g. saying Hindu prayers or enacting stories from sacred texts (such as the Ramayana) at appropriate times. ${ }^{9}$

These suggestions are accompanied by practical guidelines on prayer settings, for example, 'with some help from the local Sikh community, a simple service for all Scouts could be put together, or an area (such as a tent with clean ground sheets inside) could be set aside for quiet prayer for all Scouts'. ${ }^{10}$ On the one hand then, we can see the development of alternatives to existing structures or spaces of prayer that can be adapted to meet a parent or child's wishes on camp or in local meetings, whereas on the other hand, there are attempts to let all young people in the organisation experience different types of prayer and learn about other faiths.

\section{‘On My Honour’: The Scout Promise}

In this second example, I want to reflect more explicitly on the politics of minority religious rights for young people. Debates around multiculturalism are increasingly framed in religious terminology (Mitchell 2003; Modood 2006; Nagel and Hopkins 2010) as well as included in educational policies and agendas (Hemming 2011a). A number of conflicts and tensions about religion exist in a post-modern and post-secular society, for example on evangelical geopolitics (Dittmer and Sturm 2010) and sexuality 
(Browne, Munt and Yip 2010; Vanderbeck et al. 2011). However, debates surrounding non-Christian religious communities and the accommodation of religious needs are particularly controversial in the UK, for example around religious buildings (Valins 2000; Naylor and Ryan 2002) and schooling (Valins 2003). Here, I consider the more subtle, philosophical tensions about religious diversity and making 'place' for (youthful) religious minorities in the UK through the illustration of the Scout Promise.

In many ways, local scouting has much more flexibility with young people’s religious requirements such as catering, withdrawal requests (Joly 1988; Hemming 2011a) and clothing (Meer, Dwyer and Modood 2010) than state education through determining its own calendars and methods through devolved governance. However, tensions surrounding equal opportunities still exist through personal prejudices, naivety, indifference, or fears over the 'dilution' of scouting's identity. Indeed, whilst the previous example of prayer illustrates a flexible approach to religious minorities in scouting, these adaptations have received less attention as 'alternative' ways of scouting. I would suggest this is due to the private and more 'sacral' image of prayer. Conversely, the example of the Scout Promise is a clear illustration of some of the tensions regarding religious minorities in scouting. I would argue that this is, in part, because of the centrality of the Scout Promise as a cornerstone of scouting identity and tradition.

The Scout Promise - “On my Honour, I Promise to Do My Best, To Do My Duty to God and to The Queen, To Help Other People, And to keep the Scout Law" - is declared by every new adult or young person joining scouting in the UK. In a small ceremony, individuals make the Scout sign, a corporeal configuration of the right-hand designed to symbolise the three aspects of duty (self, other and God). In its original format, the Promise defines a Scout as Christian. However, various versions have been 
developed over time that reflect conceptualisations of other deities. Young people have the option of replacing 'God' with 'Allah', 'my Dharma' or 'Waheguru', as well as replacing their pledge to the Queen with 'to the country in which I am now living'. These alternatives are readily available in printed formats and the choice is discussed beforehand with parents and the young person. Although, it is worth mentioning here that the organisation deals primarily with established, identifiable corpus, rather than being open to a range of 'faith' alternatives. It is worth stressing that based on my experiences in scouting as a volunteer and other engagements with the organisation, however, young people's emotional responses, enthusiasm and interest in the Promise again vary. The Promise is nevertheless an important rhetorical device in the organisation's youth citizenship project, with faith leaders and adult volunteers often stressing a young person's ability or desire to 'live-out' their Scout Promise. In another letter in 1923, Rev. Harvey wrote to Baden-Powell expressing his belief that:

I fully agree with your ideal that the Scout Brotherhood should include people of all denominations of religions...it is simply my plea that our duty to our Religion must always come first and then our scouting will be of the best too. 'I promise that I will do my duty to God' - this means the whole life, of course, but a Mohammedan who is irregular in his worship, a Roman Catholic or AngloCatholic who does not go to Mass, a low Churchman or non-conformist who does not go to his Church or Chapel once at least on a Sunday is not carrying out all his Scout Promise. ${ }^{11}$ 
Here, we can sees how one particular institutional figure within the established Church viewed the Scout Promise as a device through which to regulate and judge youthful religiosities on the road to adulthood.

I now want to focus on the politics of spiritual scouting practice through looking at how the changes to the Scout Promise emerged and have been interpreted. In many ways, these can be perceived as a barometer for broader changes and attitudes towards religion and ethnic diversity. A range of media stories surfaced in 2005 regarding the Scout Promise and the right to ‘dob-dob for Allah’ (Gray and Fracassini 2005: 3), despite there being no policy change at this time. The tone was one of 'political correctness gone mad', that Baden-Powell's 'mustachios must be twirling in his grave' at this 'shiny new flexi-pledge' (Editorial 2005: 16) as the Chief Scout 'didn't allow for the complications of multi-cultural Britain' (Gray and Fracassini 2005: 3). This positioning of faith-based needs as 'complicated' and 'problematic' is pervasive in contemporary Britain. However, there is a more complex history to Scout Promise alternatives that has been ignored and this example reveals the challenges of reenvisioning the powerful institutional geographies of scouting and the potency of stereotypes about the organisation, and indeed, religious youth.

In scouting’s formative years (c.1912), an 'outlander' promise was devised for non-Britons temporarily living in the UK to pledge duty "to my [home] Country and the Country in which I am now living” instead of allegiance to the King. ${ }^{12}$ This has been used over time to diffuse tensions for individuals in countries with complex relationships to statehood and British empire such as Cyprus, the Sudan, Burma and India, as well as being more appropriate for non-Christian members through professing Duty ‘to my religion' rather than 'God'. This was only used locally, and over time, the 
authorities have expanded its uses and format. More recent policies have largely drawn on the World Scout Bureau's understanding of 'Duty to God' from 1969, which stated:

We can omit the word God as long as we use some other word which signifies faith and the belief of the individual in his [sic] union with the transcendent; with his [sic] innermost self which interacts harmoniously with the rest of creation. In this manner, we shall have not disturbed the equilibrium that exists in the text of the Scout Promise. ${ }^{13}$

This spiritual and theological interpretation has been crucial in UK Scouting in meeting the needs of various religious communities. Indeed, by 1980, the Scout Association had introduced the series of multi-faith options outlined earlier. ${ }^{14}$ By 1986, these options were truly integrated and the term 'outlander' was shelved, perceived as 'an obstacle to the development of the [Scout] Association's Relationships with members of ethnic communities. $^{15}$ The 2005 reporting in various UK newspapers was therefore misleading and fuelled in particular by continued fears over Islamic youth. Similar stories about scouting policies have also been picked up by media outlets and as topics on online discussion boards about the adaptation of the material cultures of scouting for different religious communities, in particular uniform. For example, the exemption of Sikh scouts from a rule that young people are not to wear knives with uniform to allow them to wear kirpan. ${ }^{16}$ These media examples demonstrate an extreme stereotyping of religious difference in scouting from outside the organisation. This is not to say that there are not conflicts and prejudices in local scouting structures and national forums. Indeed, there is a need for more research on the contemporary lived experiences and opinions of adults and young people from diverse religious (and non-religious) communities in scouting. In other ways, the Scout Association itself actively tries to re- 
brand or re-frame existing policies in the language of multiculturalism. For example, the current organisational language when describing religious communities always stresses religious communities compatibility with scouting, and vice versa:

The values of Scouting, such as honesty, a willingness to do things and a respect for others, and an emphasis on personal development, are particularly compatible with Hindu teachings. ${ }^{17}$

Similar expressions can be found in scouting literature on all faith-based communities, demonstrating the perceived need to connect or marry the two 'ideologies'. However, I would argue that this language has the effect of ignoring the organisation's long-term relationships and role in inter-faith dialogues and events, constructing instead brand new discourses of appropriateness, compatibility and acceptance.

The discussion in this paper of two examples where religion and different types of worship 'appear' in scouting - prayers and the Scout Promise - has shown how routine, banal and everyday aspects of the organisation have been negotiated and in some cases transformed over space and time. The discussion of the Scout Promise in particular highlights how tensions surrounding non-Christian Scouts (and by extension youth and indeed the wider religious community) are complex. Indeed, fears have been mobilised around the 'place' of religious minorities in this organisation and the changing language of recognisable features of the movement. In part, this is due to the Scout Movement's position as an imagined, nostalgic and romanticised 'British' institution. However, these fears over the dilution of scouting identity are also tied-up with broader social and cultural geographies of race, ethnicity and religion and refract wider societal attitudes to religion and contemporary life in the UK. 


\section{Conclusion}

This paper has examined the case study of the Scout Movement in the UK in order to explore the everyday, informal expressions of 'worship' by young people that occur outside of 'designated' religious spaces. Furthermore, it has examined the politics of these performances over time in the context of debates around minority religious youth and the diverse geographies of religion in the UK. There has been an original flexibility regarding religion built into the movement from its formative years, but it has also been influenced by broader social changes in British society such as increased immigration and the politics of multiculturalism. Whilst this suggests the Scout Movement is completely 'open' to religious communities, accommodating religious difference has still created tensions. Whether the response is a different corporeal configuration for prayer, or a different version of the Scout Promise, these tensions have been more politically charged, certainly in the media, when they relate to key features recognised externally as part of a nostalgic, romanticised British institution. Overall, this study of UK Scouting has raised a number of significant and wider geographical debates that warrant future research.

Firstly, there is great scope for geographers to examine the historical geographies of various multi-faith spaces that were part of a wider (informal) religious landscape of twentieth century Britain. Through utilising historical data, this analysis demonstrates how productive dialogues could be undertaken both within and outside geography on religious and spiritual spaces over time in order to contribute new insights into the production of youthful religiosities and re-thinking their designated domains. It would be interesting to further examine how religion features in broader understandings of 'duty' and 'expectations' of young people at different points in time. 
Secondly, wider debates on the geographies and spatialities of worship. This paper has illustrated alternative types and different performances of embodied worship that occur outside of Churches, synagogues and Mosques, as well as schools and formal spaces of education, in order to push 'beyond the officially sacred'. It has argued for an expanded concept of 'worship' that includes elements of religious performance or declarations of spiritual development in civil society - in this case as part of a youth organisation. In further discussions, we might more usefully theorise related concepts of 'praise' and 'commitment' - as well as how these are differently understood in various geographical contexts. Worship for and by young people needs to be examined in more depth, as well as how people's attitudes or understandings of these practices change across the lifecourse. Indeed, contemporary examinations of how young people understand and perhaps resist adult orchestrated or youth-led religious practices and performances would be interesting (on resistance in other scouting spaces and youthful acts of citizenship, see Mills 2011), particularly in the context of current debates surrounding the 'generations of decline' in British society 'neither believing or belonging' (Vaos and Crockett 2005).

Finally, on a related note, studies that examine different spaces and practices of youthful religiosities can help us attempt to understand "the blurry middle ground of belief-unbelief in the contemporary UK" (Maddrell 2009: 690) and the intersection between the 'religious' and 'secular'. As I touched upon earlier in this paper, although the Scout Association accommodates various religious beliefs and communities and has been progressive in its approach to religious expression in the past, it has created a dichotomy between those with faith and without. Furthermore, atheism has always been and remains a bar to membership for adult leaders, leading the organising to face an increasing number of written requests from members about its religious policy and 
pressure from the National Secular Society and British Humanist Association to 'make the religious oath [Scout Promise] optional' and remove this 'last bastion' regarding its equal opportunities policy (National Secular Society 2008). Similar debates about equality and perceptions of religious organisations are occurring across the youth work sector, for example the recent name change of YWCA (Young Women's Christian Association) to 'Platform 51' in England and Wales (WorldYWCA 2011). There is great scope therefore for more studies that examine the performances and politics of these blurred spaces of youthful religiosities and their complexities in a post-secular and post-modern world.

\section{$\underline{\text { Acknowledgements }}$}

This research was funded by an Economic and Social Research Council doctoral award (ES/F00737X/1 - open competition) and written up as part of their Postdoctoral Fellowship scheme (ES/I031189/1). I would like to thank the archival staff at the Scout Association, Gilwell Park. Thanks are also extended to Rhys Dafydd Jones and Peter Kraftl for their helpful comments on an earlier draft of the paper, as well as the three anonymous reviewers and Michael Brown for their suggestions.

\footnotetext{
${ }^{1}$ Scout Association Archive [hereafter SAA]/TC/24, Letter, B.H.P Smith to R. Baden-Powell, 31 August 1923

2 SAA/TC/24, Letter, Rev. H. R. Harvey to R. Baden-Powell, 28 October 1923

${ }^{3}$ SAA/TC/43/Camping 1916-1922, Nature Study, typed notes by R. Baden-Powell

${ }^{4}$ SAA/TC/33, Letter, Baden-Powell to Mr Martin, 1929

${ }^{5}$ This was replaced in 1951 by the Religious Advisory Board, in 1990 by the National Chaplaincy Team, and is now the National Team for Religious Development.

${ }^{6}$ SAA/TC/Pamphlets/R/The Religious Obligations of Scouts, London: BSA, March 1951: 7

7 SAA/Scouting and Religion Conference Notes London: Boy Scouts Association: 25

${ }^{8}$ SAA/TC/25, Letter, R. Baden-Powell to Rev. H. R. Harvey, 17 November 1921, Cited in (Proctor 2002: 141)

${ }^{9}$ Scout Association (2002) The Hindu Community in Scouting FS185023 Dec/02 $2{ }^{\text {nd }}$ Edition

${ }^{10}$ Scout Association (2008) The Sikh Community in Scouting FS185025 June/08 $3^{\text {rd }}$ Edition, my emphasis

${ }^{11}$ SAA/TC/24, Letter, Rev. H. R. Harvey to R. Baden-Powell, 28 October 1923

12 SAA/TC/119/Memo, Outlander Promise, 1942

${ }^{13}$ SAA/TC/119/Changes in the Scout Law, Comparative Study by World Scout Bureau, Geneva, 1969, VI

${ }^{14}$ SAA/TC/119/The Outlander Promise, typed notes, 1980

${ }^{15}$ SAA/TC/119/Internal Memorandum, Outlander Promise, 25 September 1986

${ }^{16}$ Kirpan is a ceremonial short sword or dagger worn by some followers of the Sikh religion that has a unique spiritual status.
} 
${ }^{17}$ Scout Association (2002) The Hindu Community in Scouting FS185023 Dec/02 $2{ }^{\text {nd }}$ Edition, my emphasis 